\title{
A Simple Example on Life Cycle Assessment of Wood Harvesting Technologies in Turkish Forestry to Mitigate Greenhouse Gas Emissions*
}

\author{
Mehmet Eker**iD, H. Oğuz ÇOBANiD \\ Isparta University of Applied Sciences, Faculty of Forestry, Forest Engineering Dept., 32260 Isparta, Turkey
}

\begin{abstract}
The forestry sector plays a key role in mitigating the negative effects of climate change. Wood supply chain (harvesting and transportation) have adverse impacts on forest environment. With respect to the interaction between forest and harvest operations, one of the key issue is the changes in carbon stock. The study on the emissions of greenhouse gas (GHG) emissions from wood supply in Turkey was undertaken to exemplify the adverse impacts of the harvest operations on global warming potential and climate change. The subject of this study, was to evaluate the primary roundwood production activities in terms of environmental impacts. The environmental impacts metrics were generally based on global warming potential, measured in $\mathrm{CO} 2$-equivalent GHG. The system boundary for this study was restricted to supply chain operations associated with roundwood harvesting and transportation. The impacts of forest operations on climate change may be reduced by choosing the best technologies for general forest conditions. LCA (life cycle assessment)-based systematic comparative analysis of different modes of harvesting systems and technological options were considered for the quantification of adverse impacts. To evaluate and control the wood supply chain, life cycle analysis can be a powerful decision mechanism. Operational modifications can be needed to reach the target of GHG minimization.
\end{abstract}

Keywords: Wood harvesting, Adverse impact of harvesting, Life cycle assessment, GHG emission, Global warming potential, Climate change.

\section{Introduction}

Wood production is currently the most important indicator of economic exploitation of forest resources. Wood supply is needed in many areas such as forest products and bioenergy sector. Approximately 4 billion $\mathrm{m}^{3}$ of roundwood is produced every year (FAO, 2020) in the worldwide and 20 million $\mathrm{m}^{3}$ in Turkey from 22.93 million hectares of forest area (FS, 2020). As the use of machinery for wood production operations has increased, so has the use of fossil fuels and oil (Athanassiadis, 2000; Klvac et al., 2003). The release of greenhouse gas (GHG) during wood harvesting is mainly connected with the manufacture, distribution, and combustion of fossil fuels via harvest machines such as chainsaw, tractors, cable yarders, and trucks (Berg and Karjalainen, 2003). Pollutant emissions from machineries because of fossil fuels, oil and lubricant leakage, and emissions from modifications in gas exchanges between the soil and the atmosphere increase the greenhouse gas effect and global warming potential (GWP) of forest operations (IPCC, 2018). Forests ecosystems and the forestry sector act a key role to mitigate climate change as a carbon sink and a carbon storage, and also as a source of available raw material with low-emission (Nabuurs et al., 2018).
Moreover, the importance of forests in combating climate change and adaptation has become even more evident and robust at the COP26 (United Nations Climate Change Conference) (COP26, 2021). This place and importance of forests on the agenda has made it necessary to act with global sensitivity even in all kinds of operations to be applied to forests.

Legal and illegal wood harvesting in all forest areas have an adverse impact on forest ecosystem and carbon stocks (Routa et al., 2012; Ellis et al., 2019). Depending on the harvesting technology, adverse impacts occur on ecosystem such as air pollution, soil disturbance, water pollution, remaining stand damage, and biodiversity losses (Marchi et al., 2018). Mechanized harvesting may also increase the emission of the GHG, methane $\left(\mathrm{CH}_{4}\right)$ and nitrous dioxide $\left(\mathrm{N}_{2} \mathrm{O}\right)$ and potentially contributing to global warming (Karjalainen and Asikainen, 1996; Garcia et al., 2014).

In recent years, life cycle assessment (LCA) methodology has been expertly used to evaluate the adverse impacts of forestry activities. Life Cycle Assessment (LCA) is a standardized methodology and powerful tool of environmental consequences,

\footnotetext{
* This study was partially presented in ICCCF'2019

**Corresponding Author: Tel: +90 2462146496 E-mail: mehmeteker@isparta.edu.tr 
environmental performances, comprehensive assessment of potential impacts associated with a product, process or activity from a life cycle perspective (Tukker, 2000; ISO, 2006). According to ISO 14040, LCA is identified that "compilation and evaluation of the inputs, outputs and potential environmental impacts of a product system throughout its life cycle". This is an extended method with a holistic approach which guarantees the comprehensiveness of an environmental evaluation, assuring its reproducibility (ISO, 1997; 1998; 2006). LCA standardization had begun at ISO Technical Committee in Paris in 1993. The standards were based on the usefulness of LCA as a methodological tool for the identifying environmental aspects of products, process or activity. LCA (ISO 14040) has a four distinct stages such as; 1) Goal and Scope Definition (ISO 14040), 2) Inventory Analysis (ISO 14049), 3) Impact Assessment (ISO 14047), and 4) Interpretation (ISO 14044) (Pryshlakivskya and Searcy, 2013; ISO, 2021).

The attempts on LCA in forestry has been scientifically appeared in the 1990s (Frühwald and Wegener, 1993) and universalized since "International Workshop: Life-Cycle Analysis - A Challenge for Forestry" (Frühwald and Solberg, 1995; Klein et al., 2015), with different forestry studies, such as evaluation of: forest cultivation, logging and transportation, processing and production of wood-based products, conversion of wood-based products, and biological refinement. (Proto et al., 2017; Abbas and Handler, 2018; D'Amato et al., 2019; Zhang et al., 2020). In studies on wood and woody biomass supply chains (harvesting and transport activities), it has been seen that evaluations are made on the oil and fuel consumption of high-tech vehicles and their outputs such as emissions (Athanissiadis, 2000; Schwaiger and Zimmer, 2001; Berg and Lindholm, 2005; Klvac et al., 2010; Engel et al., 2012; Saud et al., 2013). As well, LCA procedures have been used to compare different harvesting systems for selecting environmentally soundly technologies and eco-efficiency, in forestry (Bosner et al., 2012; Mirabella et al., 2014).

The driving factor that was effective in conducting this study was the following question; is it necessary to prefer manual or motor-manual technologies instead of mechanized technology in various forestry operations, especially in wood production operations within the framework of $\mathrm{CO}_{2}$ emission reduction targets $(2030+;-2$ $\mathrm{C}^{0}$ reduction). To the best of our knowledge, there are limited studies published on LCA for the selection of appropriate wood harvesting technologies from stump to storage. In this concept, this study aims to determine how much emission is made to produce $1 \mathrm{~m}^{3}$ of round wood with different harvesting systems, to determine whether LCA results can be taken into account for the selection of the appropriate technology, and to evaluate the environmental opportunities that may arise if simple production technologies are used within the scope of combating global climate change. The hypothesis of the study; in the wood supply chain, it is possible to reduce GHG by determining the appropriate technology; it is thought that this hypothesis can be supported by a proposition based on the difference in the amount of GHG emissions according to different technology matrices. The subject of this study, was to explore the wood harvesting activities in terms of air pollution due to felling/cutting, extraction, loading, and hauling operations. The operations were evaluated in order to support decision-makers in choosing the best technologies for general forest conditions. LCA-based systematic comparative analysis of different modes of harvesting systems and technological options were considered for the quantification of adverse impacts. The environmental impacts metrics were generally based on global warming potential (GWP), measured in $\mathrm{CO}_{2-}$ equivalent $\left(\mathrm{CO}_{2}\right.$ eq) GHG emissions (Özer, 2016; Eker and Çoban, 2019). The system boundary for this study was limited to supply chain operations relevant to roundwood harvesting including logging and also transportation phase.

\section{Materials and methods \\ 2.1. Study Site}

This study has been conducted in the context of wood supply chain from stump to storage. The local data comes from mountainous areas in Mediterranean region in Isparta Regional Directorate of Forestry (IRDF) an also general data comes from Turkey's forests. All data and calculations at the stand level were based on only tree species, brutian (calabrian) pine (Pinus brutia Ten.) harvested in Bucak Model Forest District in IRDF, which referred to average values for whole wood quantity annually harvested in Turkey. On average, $30 \%$ of the annual roundwood production in Turkey is provided from brutian pine stands. Therefore, it has been accepted that the data on brutian pine roundwood production is capable of representing the country in general. The data used in the study; it was obtained from 4 different stands, which represent the mountainous characteristic of the Mediterranean Region and where the land slope is above and below $40 \%$, where represented the availability for both manual and mechanized harvesting systems.

\subsection{System Boundary}

The actual operational process of the wood harvesting system (work flow, equipment used, working time and techniques, inputs and outputs) has been determined according to site-specific conditions. All operations were included within the system boundaries, from felling to transport to storage (Table 1). The system boundary for this study was restricted to supply chain operations associated with industrial roundwood harvesting and transportation, beginning with cutting operations and ending with the delivery of wood to a storage for selling or facilitating further processing. 
Table 1. Operational system boundaries for wood supply and its components

\begin{tabular}{lccc}
\hline $\begin{array}{l}\text { Silvicultural } \\
\text { treatment }\end{array}$ & Process & Operations & Tools and vehicles \\
\hline \multirow{2}{*}{ Final cutting } & Cutting & $\begin{array}{c}\text { Felling; processing (topping, } \\
\text { delimbing, bucking); debarking }\end{array}$ & $\begin{array}{c}\text { Axe and Chainsaw or } \\
\text { Harvester }\end{array}$ \\
& Extraction & $\begin{array}{c}\text { Skidding or forwarding or cable } \\
\text { yarding }\end{array}$ & $\begin{array}{c}\text { Farm tractors or forest } \\
\text { tractors or Cable skyline } \\
\text { Tractor loaders and trucks }\end{array}$ \\
\hline
\end{tabular}

\subsection{Data Development and Analysis}

The specific data was collected from various origins, which were; 1) measurement and calculation of actual consumption of fossil fuel and lubricant through wood supply chain, 2) calculation with constants (for example; actual machine hours was multiplied with constant of emission for GHG), 3) local averages of data concerning harvesting technologies in the specific area of IRDF, 4) transformation and generalization of the specific data to available general data in order to identify the 100 year GWP effects of annual wood harvesting in Turkey.

At the life cycle inventory (LCI) step of LCA methodology, inputs and outputs of the harvesting systems were considered (ISO 14040, 2006). Work flow of each operation was modeled using primary data, assuring that real forest conditions were taken into consideration. The functional unit is determined as $1 \mathrm{~m}^{3}$ of wood and it represents the reference point for inputs and outputs of the system. Data used in the study came from direct field observations and were collected with the motion and time studies. Each work phase of the operation was modeled evaluating the time necessary to achieve $1 \mathrm{~m}^{3}$ of wood (in hours) and hourly fuel consumption (in liter) and emissions were explored. Primary (reference) data were collected by on-site measurements (time, fuel, exhaust emission) and through visits to study sites.

Time and motion studies were executed for harvest and transport operations with stopwatch methodology by a digital chronometer (Björheden, 1991; Kanawaty, 2004; Eker and Kurt, 2019). During the field survey, data was provided on machines and equipment (number, capacity, and types), hourly fuel and oil consumption, and hourly productivity.

Time study was performed on a local scale as stand level, and a baseline data on average working times was created for each harvesting technique. Using this data as a reference value, the average working time (productivity) was estimated by making a calculation specific to the average conditions for harvesting in both coniferous and broadleaved forests of Turkey. For this, the procedure and calculation method in the Communiqué numbered 310 (GDF, 2021) was used and the working time for different techniques at different work stages and also the fossil fuel and oil consumption amounts were calculated for the acquisition of $1 \mathrm{~m}^{3}$ of wood. It was not possible to use only the data from time studies on the same stands for all technology options because some of the them were not operated and also observed. In the circumstances, average data about time and fuel consumption for the operations made in the official calculation tables (GDF, 2021). Although operating times and fuel consumptions were taken into account to measure the amount of emissions due to machine use, emissions from the manufacture of these machines were not included in the LCA procedure. The transport of workers to workplace were excluded, as well. The stand-specific data was accepted as a sample value for generalization of the data to expand it to national scale. So, uncertainties and statistical analysis had not been realized.

Two ways were followed for emission measurement. In the first, primary data were obtained by making measurements for the emission values of the chainsaw, tractor and truck with mobile emission measuring devices (EKOTEST FGA4000XDS 5 Exhaust Gas Analyzer (Özer, 2015) during the field studies. In this article, the emission measurements on the vehicles (Table 2) of the most used brands and models with average power capacity in the study area were taken as basis.

Table 2. Harvesting machines and main specifications, in this study

\begin{tabular}{lccc}
\hline Machine type & Brand and Model & Engine Type & Capacity \\
\hline Chainsaw & Husqvarna 365 & Gasoline & $4.8 \mathrm{hp} / 6.4 \mathrm{~kg}$ \\
Tractors to skid & New Holland TT55 & Diesel & $55 \mathrm{hp} / 2370 \mathrm{~kg}$ \\
Tractors to pull & & & \\
Cable skyline $(<300 \mathrm{~m})$ & John Deere 6100M & Diesel & $111 \mathrm{hp} / 5750 \mathrm{~kg}$ \\
Tractors to load & Universal 650 & Diesel & $65 \mathrm{hp} / 3000 \mathrm{~kg}$ \\
Harvester & Volco FC2121C & Diesel & $167 \mathrm{hp} / 23780 \mathrm{~kg}$ \\
Truck to transport & BMC Pro827 & Diesel & $270 \mathrm{hp} / 9050 \mathrm{~kg}$ \\
\hline
\end{tabular}


Along with this primary data, secondary data were obtained by calculating the average emission values according to the fuel and oil type used by the alternative harvesting technologies discussed in this study.The (secondary) data about operational inventory related to fuel consumption of machinery (diesel or gasoline) and emissions, such as harvester, were obtained from European Environment Agency (EEA) database and empirical experience at the similar region about harvester trial. The choice of a other database was justified by the absence of national data about the subjects. To calculate GHG emission from diesel and petrol ignition; time consumption and energy (fuel) expenditure were used in the procedure. GHG emissions of machineary of wood harvesting and transportation can be estimated from the following expression (Eker and Çoban, 2019):

$E m=E m F \times E n$

$E m=$ GHG emission, g per unit of work,

$E m F=$ Emission factor, $\mathrm{g} / \mathrm{kg}$ fuel (EMEP/EEA, 2019)

$E n=$ Amount of energy consumed or distance travelled for a given activity (cutting of tree, extraction, longdistance transportation), $\mathrm{kg}$ (type of fuel; diesel, gasoline.

The external data coming from EEA database and literature provided data on the emission factors of harvest machineries. The data contained the values for machines and vehicles on hydrocarbon $(\mathrm{HC})$, carbon monoxide $(\mathrm{CO})$, nitrous oxides ( $\mathrm{NOx}$ ), particulate matter $(\mathrm{PM})$, and carbon dioxide $\left(\mathrm{CO}_{2}\right)$. Every kind of machinery distinguished the results depending on machine type (chainsaw, tractor, cable-crane, etc.), engine power (diesel or gasoline), and capacity according to the equipment generally usable in Turkish forestry to perform the described operations. The environmental impacts metrics studied were global warming potential (GWP), measured in $\mathrm{kg}$ of $\mathrm{CO}_{2} \mathrm{eq}$ GHG emissions for 100 year effects in terms of time scale.

Considering the compatibility of various techniques used in different stages of the wood harvesting process, 3 technology classes based on the mechanization level (basic, intermediate, and advanced technologies) for harvesting systems were created (Table 3). The options according to technology level implied the use of from basic to more mechanized alternatives, provided by special firm located in Turkey and GDF. Since available data about environmental impacts on forestry operations were not on a special database, every step was modeled according to primary and secondary data provided by different sources.

Table 3. Harvesting system configuration based on alternative technology level

\begin{tabular}{lc}
\hline System configuration & Technology Level (Alternatives) \\
\hline $\begin{array}{l}\text { Chainsaw felling and processing, axe debarking; Gravity skidding by human } \\
\text { force; Loading by tractor loader and truck transportation }\end{array}$ & Basic \\
Chainsaw felling and processing, debarking with chainsaw log debarker; & \\
$\begin{array}{l}\text { Skidding with tractors or pulling by tractor cable line; Loading by tractor } \\
\text { loader and truck transportation }\end{array}$ & Intermediate \\
$\begin{array}{l}\text { Felling and processing by harvester + Debarking with chainsaw log debarker; } \\
\text { Cable }\end{array}$ & Advanced \\
yarding with skyline; Loading by tractor loader and truck transportation &
\end{tabular}

It is important to remark that the topographical and site-specific conditions of Turkey's forests limit some forest machines such as harvester. This issue and further considerations were taken into consideration to calculate and choice of technology options. LCA methodology was used to perform a comparative analysis of different technological options for wood harvesting in order to identify the appropriate harvesting technology with lowest potential impacts through whole supply chain.

\section{Results}

Using primary and secondary data, the working times and the fuel consumed by the various machines used in different stages of wood harvest operations could be determined. The amount of fuel consumed could be calculated per hour and per cubic meter of wood product according to operation efficiency (Table 4). When the fuel consumed was also converted to weight units for the calculation of GHG emissions, for example, the average amount of fuel consumed in extraction $1 \mathrm{~m}^{3}$ of wood by tractor was calculated as $0.54 \mathrm{~kg}$.
In the scale of wood harvest operations, GHG emission values related to fuel consumption had been determined in order to measure the impact of the operations on global warming. GHG emissions in grams per unit cubic meter are shown in the Table 5. For example, the amount of $\mathrm{CO}_{2}$ emissions that emerge on a $50 \mathrm{~km}$ route to transport wood was around $3.2 \mathrm{~kg}$.

The comparison of results of the three technological options for the wood harvest system was shown in Table 6 . The lowest emissions were belonging to the basic technology where gravity skidding was operated. In this system structure, $5.69 \mathrm{~kg}$ of $\mathrm{CO}_{2}$ was emitted to air for the supply of $1 \mathrm{~m}^{3}$ wood raw material. $\mathrm{CO}_{2}$ had the highest GHG emission rate in the GWP impact category. For example, approximately $79 \%$ of $\mathrm{CO}_{2}$ was emitted to air during the cutting phase because chainsaw was used extensively. In cutting operations related to the use of harvesters, the $\mathrm{CO}_{2}$ rate could reach to $98 \%$, which was similar to rate of Mirabella et al. (2014). 
Table 4. Time and fuel consumption of forest machines for operations

\begin{tabular}{lcccc}
\hline \multirow{2}{*}{ Operations } & \multirow{2}{*}{$\begin{array}{c}\text { Working } \\
\text { Time }\left(\mathrm{h} / \mathrm{m}^{3}\right)\end{array}$} & \multicolumn{2}{c}{$\begin{array}{c}\text { Fuel } \\
\text { Consumption }\end{array}$} & Fuel type \\
\cline { 3 - 4 } & & $(1 / \mathrm{h})$ & $\left(1 / \mathrm{m}^{3}\right)$ & \\
\hline Felling + Delimbing + Bucking with chainsaw & 0.23 & 0.90 & 0.21 & Gasoline \\
Debarking with chainsaw & 0.85 & 0.58 & 0.49 & Gasoline \\
Felling by harvester & 0.08 & 12.00 & 0.96 & Diesel \\
Pulling by Tractor cable $(100 \mathrm{~m})$ & 0.16 & 4.00 & 0.64 & Diesel \\
Skidding with Tractor $(100 \mathrm{~m})$ & 0.25 & 6.00 & 1.50 & Diesel \\
Skidding with MB/Tractor $(100 \mathrm{~m})$ & 0.14 & 8.00 & 1.12 & Diesel \\
Cable skyline (300 m) & 0.18 & 10.00 & 1.80 & Diesel \\
Loading wth tractors/loaders & 0.09 & 8.00 & 0.72 & Diesel \\
Hauling by trucks (50km) & 1.00 & 17.00 & 1.18 & Diesel \\
\hline
\end{tabular}

Table 5. GHG emissions from fuel combustion in forest machines

\begin{tabular}{lccccccc}
\hline \multirow{2}{*}{ Operations } & \multicolumn{7}{c}{ Emissions $\left(\mathrm{g} \mathrm{GHG} / \mathrm{kg}\right.$ fuel per $\mathrm{m}^{3}$ of wood) } \\
\cline { 2 - 8 } & $\mathrm{CO}_{2}$ & $\mathrm{CO}$ & $\mathrm{CH}_{4}$ & $\mathrm{~N}_{2} \mathrm{O}$ & $\mathrm{NOx}$ & $\mathrm{NH}_{3}$ & NMVOC \\
\hline Felling + Delimbing + Bucking & 590.922 & 114.745 & 3.162 & 0.003 & 0.511 & 0.001 & 42.011 \\
with Chainsaw & & & & & & & \\
Debarking with chainsaw & 1385.410 & 269.019 & 7.414 & 0.007 & 1.198 & 0.001 & 98.495 \\
Felling by harvester & 2578.560 & 6.261 & 0.040 & 0.113 & 23.232 & 0.007 & 1.630 \\
Skidding by Tractor cable & 1719.040 & 4.174 & 0.027 & 0.075 & 15.488 & 0.004 & 1.086 \\
Skidding with Tractor & 4029.000 & 9.783 & 0.062 & 0.176 & 36.301 & 0.010 & 2.546 \\
Skidding with MB/Tractor & 3008.320 & 7.305 & 0.047 & 0.131 & 27.104 & 0.008 & 1.901 \\
Cable skyline & 4834.800 & 11.740 & 0.075 & 0.211 & 43.561 & 0.012 & 3.055 \\
Loading wth tractors/loaders & 1933.920 & 4.696 & 0.030 & 0.084 & 17.424 & 0.005 & 1.222 \\
Hauling by trucks (50km) & 3169.480 & 7.696 & 0.049 & 0.138 & 28.556 & 0.008 & 2.003 \\
\hline
\end{tabular}

Table 6. GHG emissions from different technology matrices

\begin{tabular}{|c|c|c|c|c|}
\hline \multicolumn{5}{|c|}{ Emissions $\left(\mathrm{kg} / \mathrm{m}^{3}\right)$} \\
\hline $\begin{array}{l}\text { Technology Level } \\
\text { (Alternatives) }\end{array}$ & System configuration & $\mathrm{CO}_{2}$ & $\begin{array}{lllll}\mathrm{CO} & \mathrm{CH}_{4} & \mathrm{~N}_{2} \mathrm{O} & \mathrm{NOx} & \mathrm{NH}_{3}\end{array}$ & NMVOC \\
\hline Basic (Minimum) & $\begin{array}{l}\text { Chainsaw felling }+ \text { Axe }+ \\
\text { Gravity skidding }+ \text { Loader }+ \\
\text { Truck }\end{array}$ & 5.69 & 0.130 .00320 .00020 .04650 .0000 & 0.0452 \\
\hline $\begin{array}{l}\text { Intermediate } \\
\text { (ordinary) }\end{array}$ & $\begin{array}{l}\text { Chainsaw felling+ Debarker }+ \\
\text { Tractor Cable }+ \text { Loader }+ \\
\text { Truck }\end{array}$ & 8.79 & 0.400 .01070 .00030 .06320 .0000 & 0.1448 \\
\hline $\begin{array}{l}\text { Advanced } \\
\text { (Maximum) }\end{array}$ & $\begin{array}{l}\text { Harvester +Debarker + Cable } \\
\text { yarder + Loader + Truck }\end{array}$ & 13.9 & 0.290 .00760 .00060 .11400 .0000 & 0.1064 \\
\hline
\end{tabular}

In parallel with the change in the level of technology used in forestry operations, GHG emissions were also changing. Because there was a case that is sensitive to the change of fossil fuel use. According to the sensitivity analysis we conducted in this study, half of the total GHG emissions contributing to global warming and climate change in operations performed without going to any mechanization in the use of basic technology, ie. removal from the stand, originates from the secondary transport of wood raw material, namely transportation. Basic technology based on motor-manual operations could lead to much lower emissions. Emission levels varied between 9 and $14.2 \mathrm{~kg} \mathrm{CO} 2 \mathrm{eq} / \mathrm{m}^{3}$ in mechanized operations (intermediate and advanced) (Table 7). At the intermediate technology level, $19 \%$ of the total emission due to the introduction of agricultural tractors was due to the extraction activities. In advanced technology, $34 \%$ of the emission occurred at this stage, considering that the extraction activities were carried out completely or mostly by machinery. In all three technology options, the responsibility of truck transportation in the formation of $\mathrm{CO}_{2}$ emissions (for $50 \mathrm{~km}$ ) was $55 \%$ in basic technology, while it was $23 \%$ in advanced technology.

Considering the 100-year impact period to determine the global warming potential of GHG emissions during the production of wood, it was determined that the emission amounts of methane and nitrous oxide emissions in terms of carbon dioxide were collected and the equivalent effect of $6-14 \mathrm{~kg}$ carbon dioxide per $\mathrm{m}^{3}$ (Table 8). 
Table 7. Variation on GHG emissions per unit production respect to technology level

\begin{tabular}{lccccc}
\hline Operations & System & $\begin{array}{c}\mathrm{CO}_{2} \mathrm{eq} \\
\mathrm{kg} / \mathrm{m}^{3}\end{array}$ & Basic & Interm. & Advanced \\
\hline Felling + Delimbing + Bucking with Chainsaw & $(1)$ & 0.67 & $11 \%$ & $7 \%$ & \\
Debarking with chainsaw & $(2)$ & 1.57 & & $17 \%$ & $11 \%$ \\
Felling by harvester & $(3)$ & 2.61 & & $18 \%$ \\
Skidding by Tractor cable & $(4)$ & 1.74 & & $19 \%$ & \\
Skidding with Tractor & $(5)$ & 4.08 & & & \\
Skidding with MB/Tractor & $(6)$ & 3.05 & & & $34 \%$ \\
Cable skyline & $(7)$ & 4.90 & & & \\
Loading wth tractors/loaders & $(8)$ & 1.96 & $34 \%$ & $21 \%$ & $14 \%$ \\
Hauling by trucks (50km) & $(9)$ & 3.21 & $55 \%$ & $35 \%$ & $23 \%$ \\
Basic & $(1+8+9)$ & 5.84 & $100 \%$ & & \\
Intermediate & $(1+2+4 / 5+8+9)$ & 9.16 & & $100 \%$ & \\
Advanced & $(3+2+7+8+9)$ & 14.26 & & & $100 \%$ \\
\hline
\end{tabular}

Table 8. Global warming potential of operation technologies

\begin{tabular}{lcccc}
\hline \multicolumn{5}{c}{ GWP 100 years $\mathrm{CO}_{2}$ eq } \\
\hline Operations & System & $\mathrm{kg} / \mathrm{m}^{3}$ & ton $/ 20 \mathrm{Mm}^{3} \%$ of $20 \mathrm{Mm}^{3}$ \\
\hline Felling + Delimbing + Bucking with Chainsaw & $(1)$ & 0.67 & 13418.3 & $90 \%$ \\
Debarking with chainsaw & $(2)$ & 1.57 & 31458.9 & $40 \%$ \\
Felling by harvester & $(3)$ & 2.61 & 52262.3 & $10 \%$ \\
Skidding by Tractor cable & $(4)$ & 1.74 & 34841.6 & $20 \%$ \\
Skidding with Tractor & $(5)$ & 4.08 & 81659.9 & $20 \%$ \\
Skidding with MB/Tractor & $(6)$ & 3.05 & 60972.7 & $5 \%$ \\
Cable skyline & $(7)$ & 4.90 & 97991.9 & $10 \%$ \\
Loading wth tractors/loaders & $(8)$ & 1.96 & 39196.8 & $95 \%$ \\
Hauling by trucks (50km) & $(9)$ & 3.21 & 64239.1 & $100 \%$ \\
Basic & $(1+8+9)$ & 5.84 & 116854.1 & \\
Intermediate & $(1+2+4 / 5+8+9)$ & 9.16 & 183154.7 & \\
Advanced & $(3+2+7+8+9)$ & 14.26 & 285149.1 & \\
Mixed & $\mathrm{All}$ & & & 167510.4 \\
\hline
\end{tabular}

Considering the average wood harvesting in Turkey was annually 20 million $\mathrm{m}^{3}$, the total carbon dioxide equivalent emissions of the global warming potential was estimated to be at least about 117 thousand tons. However, if $10 \%$ of the production of 20 million cubic meters was made by harvesting machines, $40 \%$ of the shells were debarked by a chainsaw and $55 \%$ of the product was removed from the stand by mechanization, it was determined that approximately 170 thousand tons of $\mathrm{CO}_{2}$ eq GWP would be produced.

\section{Discussions}

Wood harvesting in forestry; it has generally various impacts on the forest ecosystem including soil, water, air and stand structure (Akay et al., 2006; Akay et al., 2021; Buğday, 2011; Ünver and Acar, 2011; Gülci et al., 2015). In this study, only climate change impacts through GWP indicator of wood harvest operations was taken into account, although there are many effect categories (ozon depletion, toxicity, acidification, eutrophication, etc.) in the LCA methodology (Mirabella et al., 2014). However, considered in LCA procedure, since many LCIA methodologies are not site specific (Mirabella et al., other adverse effects of harvest operations were not included in the scope of this study, since it could be difficult to quantify with LCA methodology whole impacts of harvesting systems on forest soil, hydrogeological cycles, and stand structures (Straka and Layton 2010).

Inventory based modelling approach (Karjalainen et al., 2001), was used on the analysis of existing and actual data, in this study. As summarized by Bosner et al. (2012), the data were obtained from national statistics regarding actual forestry (area, cubic meters of harvested timber, etc), operational data and time study data related to productivity and fuel consumption per work or time unit. Berg and Karjalainen (2003) highlighted the importance of the origin and quality of data in LCA. Their study was focused on data of environmental impacts of forest operations in Sweden and Finland. They compared records of $\mathrm{CO}_{2}$ emissions from logging operations, transport of timber to industry and some silvicultural activities. The data and specific findings of the study is typically local scale, but local impacts are not 2014). 
LCA could provide for the comparison of three kinds of harvest systems, identifying which was the most appropriate technology. At the local scale, in the study area, different options were evaluated, collecting specific/primary data for this area. This ensured for the determination of the environmental impacts related to harvest operation. The lowest emission values, within the wood supply systems with 3 different technology levels for $1 \mathrm{~m}^{3}$ of wood from the stand to the storage, was obtained for the basic technology where manual extraction with gravity has been operated. Intermediate and advanced technologies consumed more fossil fuels for the machine use, so overall emissions increased such as in literature (Berg and Lindholm 2005; Michelsen et al. 2008; Mirabella et al., 2014).

Furthermore, the advanced technology option was the most favorable one because of higher productivity. However, it had the high fuel consumption and emissions, therefore, it was unsuitable in terms of GWP effects. Basic technology proved as an appropriate solution with the lowest atmospheric impacts. Depending on the operational productivity, advanced technology could become the available option to be adopted in case of an appropriate control of engine emissions, when time scale of the impacts was taken into consideration.

When a sensitivity analysis had been applied, for example, harvesting machine in the advanced technology option was used at the higher productivity (about $50 \%$ increase), then result showed that advanced technology converged to intermediate technology in terms of GWP impacts because of higher productivity of machines in fuel use and emissions. However, Turkey's forest conditions may not allow advanced harvest machinery to be used everywhere or providing of higher productivity of harvester and cable logging may not be possible. On no circumstances, diesel particulate filters or selective catalytic reduction systems may be a useable option to reduce particulate matter and nitrous oxides emissions (Mirabella et al., 2014). The highest emission impacts in wood supply chain were caused by primary and secondary transport. Truck transportation was responsible for highest emission in all technological options regardless of the level of mechanization like that literature (Gonzalez-Garcia et al., 2009).

According to generalized calculations, the carbon content of wood raw material produced in Turkey is about 6.5 million tons annually. The $\mathrm{CO}_{2}$ content of the atmosphere over the carbon content of the wood is approximately 24 million tons. Accordingly, it is removed or harvested $\mathrm{CO}_{2}$ from the forest in Turkey during manufacturing operations is $0.7 \%$ of the total $\mathrm{CO}_{2}$ content. This rate is less than 1 percent (Eker and Çoban, 2019). Previous analysis showed that the fossil energy used in the supply chain is generally a small fraction of the energy content of the woody products, even though its transportation over long distance (Marchi et al., 2018).

The world's carbon reservoir is 48000 gigatons. The amount of carbon emissions caused by the use of fossil fuel and cement is 6.3 gigatons. Its $\mathrm{CO}_{2}$ equivalent is 23.1 gigatons. On the other hand, it is a fact that GHG emissions are realized for production operations into the atmosphere. When taken into consideration cement use in the world, vehicles in traffic, factories, etc., then it is possible to say that the impact of wood harvest operations on global warming and climate change is comparatively quite low (Eker and Çoban, 2019). In countries where high level of mechanization and advanced technologies are applied, the amount of greenhouse gas emitted per unit cubic meter is in the range of 8-16 $\mathrm{kg} \mathrm{CO}_{2}$ eq (Puettmann et al., 2010). In recent years, however, the use of alternative fuels and technological advances in vehicles have reduced fossil fuel consumption and conversion.

\section{Conclusions}

In this study, the GHG emissions of 3 different technology options for wood harvest that have the potential to be used in the wood supply chain were evaluated according to the GWP effect with the LCA methodology, using the wood harvesting system data of the Turkish forests with the support of the data obtained from the model forests at local scale. GHG emission impacts was dependent on the fuel consumption, so it was very important to select appropriate technology level to reduce the hours necessary to perform each operation. It is not possible to describe a true technology that would be suitable for all types of forestland in terms of stand, topography, climate and operating conditions. However, if it is possible to use many technological options in a stand, if reducing the effects of GHG is the primary goal, then it is necessary to create a low emission production system configuration. However, if the stand level conditions are suitable for working with high efficiency, it is possible to work with advanced technology, that is, with a high level of mechanization. When harvesting is made with high-efficiency machines, emission values are low because less time and fuel will be spent per cubic meter of wood. However, in situations where work efficiency is not prioritized and ergonomic principles are relaxed, using the basic technology which is traditionally based on the combination of ground skidding with gravity and human force also offers an important opportunity for low GHG emissions. When it becomes mandatory to reduce emissions in all environmental activities, including forest harvest operations, it may be necessary to prefer basic technologies based on human physical strength due to the negativities based on machinery and fuel exports in developing countries such as Turkey.

Moreover, the traditional wood supply chain, also examined in this study, can be shortened by various measures such as removing the debarking step. In order to reduce the amount of GHG emissions caused by secondary transport (hauling), forest storage or primary facilities to process wood raw materials can be built more closer to the harvesting sites. Additionally, in general, 
the impacts of wood harvest operations on climate change may be reduced by the introduction of new approach and implementations such as climate smart forestry. Optimized operational planning, scheduling, small scale equipments, new machinery design, and altering harvesting method to shorten procurement process in the forest may reduce adverse impacts related to GHG emission and also climate change. Operational modifications are needed to reach this target, such as reduced wood waste, narrower haul roads, and lower impact skidding methods. Further, to evaluate and control the wood supply chain, on the scale of time and space, LCA can be a powerful decision mechanism. Therefore, future studies should be addressed in the following aspects: 1) LCA on the firewood harvesting process, separately or together with industrial wood production by making an energy audit, 2) comprehensive analysis of woody biomass harvesting including stump mass from managed forests with the same environmentally assessment procedure, 3 ) cradle-to-gate LCA including the production processes of harvesting machines, 4) evaluating of wood harvest operations in certificated forestry applications by using of LCA in terms of all adverse impacts.

\section{Ethics Committee Approval: N/A.}

Peer-review: Externally peer-reviewed.

Author Contributions: Concept: M.E.; Design: M.E. and H.O.Ç.; Supervision: M.E.; Resources: M.E. and H.O.Ç.; Data Collection: M.E.; Analysis: M.E.; Literature Search: M.E. and H.O.Ç.; Writing Manuscript: M.E.; Critical Review: M.E. and H.O.Ç.

Conflict of Interest: The authors have no conflicts of interest to declare.

Financial Disclosure: The authors declared that this study has received no financial support

Cite this paper as: Eker, M., Çoban, H.O., 2021. A Simple Example on Life Cycle Assessment of Wood Harvesting Technologies in Turkish Forestry to Mitigate Greenhouse Gas Emissions, European Journal of Forest Engineering, 7(2):67-76.

\section{References}

Abbas, D., Handler, R.M., 2018. Life-cycle assessment of forest harvesting and transportation operations in Tennessee. J. Clean. Prod., 176: 512-520.

Acuna, M., Strandgard, M., 2017. Impact of climate change on Australian forest operations. Australian Forestry, 80(5): 299-308.

Akay. A.E., Yımaz, M., Tonguç, F., 2006. Impact of Mechanized harvesting Machines on Forest Ecosystem: Residual Stand Damage. Journal of Applied Sciences, 6(11): 2414-2419.
Akay, A. E., Bilici, E., Taş, İ., Özkan, D., 2021. Türkiye Ormanciliğinda Mekanik Üretim Araçlarinin Kullanimi: Çanakkale Örneği. IV. Ulusal Ormancılık Kongresi. 15-16 Kasim. Antalya, Turkey. 448-458. (In Turkish).

Athanassiadis, D. 2000. Energy consumption and exhaust emissions in mechanized timber harvesting operations in Sweden. Sci. Total Environ., 255:135143

Berg, S., Karjalainen, T., 2003. Comparison of greenhouse gas emissionfrom forest operations in Finland and Sweden. Forestry, 76(3):271-284.

Berg, S., Lindholm, E.L., 2005. Energy use and environmental impacts of forest operations in Sweden. J. Cleaner Prod., 13:33-42.

Björheden, R., 1991. Basic time concepts for international comparisons of time study reports. Journal of Forest Engineering, 2(2): 33-39.

Bosner, A., Porsinsky, T., Stankic, I., 2012. Forestry and Life Cycle Assessment, Global Perspectives on Sustainable Forest Management, Dr. Clement A. Okia (Ed.), ISBN: 978-953-51-0569-5, InTech.

Buğday, E., 2011. Environmental Damages of Forest Harvesting Operations. MSc. Thesis. Çankırı Karatekin University, Graduate School of Natural and Applied Sciences, Çankırı. 64 p.

COP26, 2021. The Negoatitions Explained.UN Climate Change Conference, 31 Oct.-12 Nov., UK Partnership with Italy. https://ukcop26.org/wpcontent/uploads/2021/11/COP26-.pdf (Accessed: 20.11.2021)

D’Amato, D., Gaio, M., Semenzin, E., 2019. A review of LCA assessments of forest-based bioeconomy products and processes under an ecosystem services perspective. J. Sci. Total. Environ., 12: 359-367.

Eker, M., 2016. Life Cycle Inventory in wood harvesting for sensitive forest operations. 1st Inter. Symposium of Forest Engineering and Technologies-FETEC 2016, 2-4 June, Bursa, Book of Abstracts, p. 31.

Eker, M., Önal, Y.E., 2017. Life cycle assessment for wood harvesting in Turkish forestry conditions. International Symposium on New Horizons in Forestry, 18-20 October, Proceedings \& Abstract Book, Isparta, p. 431.

Eker, M., Kurt, Y., 2019. Development of a time measurement and recording tool for forestry works. Turkisj Journal of Forestry, 20(3): 157-167.

Eker, M, Çoban, H.O., 2019. The Relationship Between Forest Operations and Climate Change. International Conference on Climate Change and Forestry, November 13-14, Antalya, Turkey.

Ellis, W.P., Gopalakrishna, T., Goodman, R.C., Putzc, F.E., Roopsind, A., Umunay, P.M., Zalman, J., Ellis, E.A., Mo, K., Gregoiree, T.G., Griscom, B.W., 2019. Reduced-impact logging for climate change mitigation (RIL-C) can halve selective logging emissions from tropical forests. Forest Ecology and Management 438: 255-266. 
EMEP/EEA, 2019. EMEP/EEA air pollutant emission inventory guidebook 2019. European Environment Agency, $81 \mathrm{p}$.

Engel, A.M., Wegener J., Lange, M., 2012. Greenhouse gas emissions of two mechanized wood harvesting methods in comparison with the use of draft horses for logging. Eur. J. For. Res., 131:1139-1149.

FAO. 2020. Global Forest Resources Assessment 2020: Main report. Food and Agriculture Organization of United Nations, Rome. 186 p.

FI, 2020. Forestry Statistics:2020, General Directorate of Forestry. www.ogm.gov.tr (Accessed: 18.11.2021)

Frühwald, A., Wegener G., 1993. Energiekreislauf Holzein Vorbild für die Zukunft. HOLZ- Erzeugung und Verwendung-Ein Kreislauf der Natur. 15. DreiländerHolztagung in Garmisch-Partenkirchen, pp. 49-60.

Frühwald, A., Solberg, B., 1995. LCA - A Challenge for Forestry and Forest Products Industry. Proceedings of the International Workshop organised by the European Forest Institute and the Federal Research Centre for Forestry and Forest Products, 3-5 May, ISBN:952-9844-16-6, Hamburg, Germany.

Gonzalez-Garcia, S., Berg, S., Feijoo, G., Moreira, M.T., 2009. Environmental impacts of forest production and supply of pulpwood: Spanish and Swedish case studies. Int J Life Cycle Assess 14(4):340-353.

Gülci, N., Akay, A. E., Erdaş, O., Gülci, S., 2015. Forest operations planning by using RTK-GPS based digital elevation model. Journal of the Faculty of Forestry Istanbul University (JFFIU), 65(2): 59-68.

IPCC, 2018. Global Warming of $1.5{ }^{0} \mathrm{C}$. The Intergovernmental Panel on Climate Change. Switzerland, $30 \mathrm{p}$.

ISO, 1997. ISO 14040: Environmental Management Life Cycle Assessment - Principles and Framework. International Organization

ISO, 1998. ISO 14041: Environmental Management Life Cycle Assessment - Goal and Scope, Definition and Inventory Analysis. International Organization for Standardization, Geneva, Switzerland.

ISO, 2006. ISO 14000: Environmental management. International Organization for Standardization, Geneva, Switzerland.

ISO, 2021. ISO 14044: Environmental management Life cycle assessment - Requirements and guidelines. ISO 14044:2006, International Organization for Standardization, Geneva, Switzerland.

García, S.G., Moreirab, M.T., Diasa, A.C., Yudegoc, M.B., 2014. Cradle-to-gate Life Cycle Assessment of forest operations in Europe: environmental and energy profiles. Journal of Cleaner Production 66:188-198.

Heinimann, H.R., 2012. Life cycle assessment (LCA) in forestry - state and perspectives. Croat J For Eng 33:357-372.
Kanawaty, G., 2004. İş Etüdü. (Çev. Zuhal AKAL) MPM Yayınları, Yayın No:29, Ankara.

Karjalainen, T., Asikainen, A., 1996. Greenhouse gas emissions from the use of primary energy in forest operations and long-distance transportation of timber in Finland. Forestry, 69(3): 215-228.

Klein, D., Wolf, C., Schulz, C., Weber-Blaschke, G., 2015. 20 years of life cycle assessment (LCA) in the forestry sector: state of the art and a methodical proposal for the LCA of forest production. The International Journal of Life Cycle Assessment, 20: 556-575.

Klvac, R., Ward, S., Owende, P., Lyons, J., 2003. Energy audit of wood harvesting systems. Scand J For Res 18(2):176-183.

Marchi, E., Chung, W., Visser, R., Abbas, D., Nordfjell, T., Mederski, P.S., McEwan, A., Brink, M., Laschi, A., 2018. Sustainable forest operation (SFO): A new paradigm in a changing world and climate. Science of the Total Environment 634:1385-1397.

Michelsen, O., Solli, C., Strømman, A.H., 2008. Environmental impact and added value in forestry operations in Norway. J Ind Ecol 12:69-81.

Mirabella, N., Castellani, V., Sala, S., 2014. Forestry operations in the alpine context: Life cycle assessment to support the integrated assessment of forest wood short supply chain. Int J Life Cycle Assess 19: 1524-1535.

Nabuurs, G, J., Verkerk, P. J., Schelhass M. J., Olabarria J.R.G., Trasobares, A., Cienciala, E., 2018. Climate Smart Forestry: mitigation impacts in three European regions. From Science to Policy 6. European Forest Institute.

Özer, D., 2016. Life Cycle Inventory for Wood Harvesting in Forestry (Ormancilikta Odun Üretiminde Yaşam Döngüsü Envanter Analizi), M.Sc Thesis, Graduate School of Natural and Applied Sciences Department of Forest Engineering, Süleyman Demirel University, Isparta.

Proto, A. R., Bacenetti, J., Macrì, G., Zimbalatti, G., 2017. Roundwood and bioenergy production from forestry: Environmental impact assessment considering different logging systems. J. Clean. Prod. 165: 1485-1498.

Pryshlakivskya, J., Searcy, C., 2013. Fifteen years of ISO 14040: a review. Journal of Cleaner Production 57(15):115-123.

Puettmann, M., R.D. Bergman, S. Hubbard, L. Johnson, B. Lippke, Wagner, F., 2010. Cradle-to-gate lifecycle inventories of US wood products production CORRIM Phase I and Phase II Products. Wood and Fiber Science, 42(CORRIM Special Issue):15-28.

Routa, J., Kellomäki, S., Peltola, H., 2012. Impacts of intensive management and landscape structure on timber and energy wood production and net $\mathrm{CO}_{2}$ emissions from energy wood use of norway spruce. Bioenerg. Res. 5:106-123. 
Saud, P., Wang, J., Lin, W., Sharma, B.D., Hartley, D.S., 2013. A life cycle analysis of forest carbon balance and carbon emissions of timber harvesting in West Virginia. Wood Fiber Sci 45:1-18.

Schwaiger, H., Zimmer, B., 2001. A comparison of fuel consumption and greenhouse gas emissions from forest operations in Europe. In: Karjalainen $\mathrm{T}$, Zimmer B, Berg S, Welling J, Schwaiger H, Finér L, Cortijo P (eds) Energy, carbon and other material flows in the life cycle assessment of forestry and forest products. European Forest Institute, Joensuu, pp 33-50.

Schweier, J., Magagnotti, N., Labelle, E.R., Athanassiadis, D., 2013. Sustainability Impact Assessment of Forest Operations: A Review. Curr. For. Rep. 5:101-113.
Straka, T.J., Layton, P.A., 2010. Natural resources management: life cycle assessment and forest certification and sustainability issues. Sustainability 2:604-623.

Tukker, A, 2000. Life cycle assessment as a tool in environmental impact assessment. Environmental Impact Assessment Review 20(4):435-456.

Ünver, S., Acar. H. H., 2011The Effects of Wood Raw Material Production Activities on Wood Quality Classes. Artvin Çoruh University Faculty of Forestry Journal, 6(1):128-134.

Zhang, X., Zhang W., Xu, Dayu., 2020. Life cycle assessment of complex forestry enterprise: A case study of a forest-fiberboard integrated enterprise. Sustainability, 12(4147):18 p. 